Canadian University Music Review

Revue de musique des universités canadiennes

\title{
Violet Balestreri Archer: Milestones of a Career
}

Volume 16, numéro 1, 1995

Voices of Women: Essays in Honour of Violet Archer

Voix de femmes : mélanges offerts à Violet Archer

URI : https://id.erudit.org/iderudit/1014412ar

DOI : https://doi.org/10.7202/1014412ar

Aller au sommaire du numéro

Éditeur(s)

Canadian University Music Society / Société de musique des universités

canadiennes

\section{ISSN}

0710-0353 (imprimé)

2291-2436 (numérique)

Découvrir la revue

Citer ce document

(1995). Violet Balestreri Archer: Milestones of a Career. Canadian University Music Review / Revue de musique des universités canadiennes, 16(1), 5-6.

https://doi.org/10.7202/1014412ar

All Rights Reserved (C Canadian University Music Society / Société de musique des universités canadiennes, 1995
Ce document est protégé par la loi sur le droit d'auteur. L’utilisation des services d'Érudit (y compris la reproduction) est assujettie à sa politique d'utilisation que vous pouvez consulter en ligne.

https://apropos.erudit.org/fr/usagers/politique-dutilisation/ 


\section{VIOLET BALESTRERI ARCHER: MILESTONES OF A CAREER}

\section{Academic Background}

McGill University, Teacher's Licentiate in piano (1934); B.Mus. in composition (1936). Royal Canadian College of Organists, Associate Diploma (1938). Yale University, B.Mus. in composition (1948); M.Mus. in composition (1949)

\section{Honorary Degrees}

McGill University, D.Mus. (1971); Royal Canadian College of Organists, Honorary Fellow (1985); University of Windsor, D.Mus. (1986); University of Calgary, Honorary LL.D. (1989); Mount Allison University, D.Mus. (1992); University of Alberta, Honorary LL.D. (1993)

\section{Academic Positions}

Continuing positions: McGill University, Instructor (1943-47); North Texas State College, Resident Composer (1950-53); University of Oklahoma, Assistant Professor (1953-61); University of Alberta, Associate Professor (196270), Professor (1970-78), Chairman of Theory and Composition (1962-78); Professor of Music Emerita

Visiting lecturer: University of Alberta (summers of 1948 and 1949, 1982-83, 1988-90); Cornell University (summer 1952); University of Saskatchewan (November 1978, March 1990); University of Calgary (February 1986); Grande Prairie Regional College (September 1987); Banff School of Fine Arts (summers of 1978 and 1979); University of Alaska (April 1988 and 1992)

\section{Scholarships and Awards}

Composition Trophy, Quebec Music Festival (1938)

Four Scholarships for Composition, McGill University (1940-44)

Grants for study abroad, Quebec Government (1946 and 1948)

Bradley Keeler Memorial Scholarship, Yale University (1947)

Charles Ditson Fellowship, Yale University (1948)

Woods Chandler Prize for Composition, Yale University (1949)

Bursary for study abroad, Ladies Morning Musical Club, Montreal (1949)

Fellowship to MacDowell Colony, MacDowell Club of Oklahoma City (1956) Canada Council Senior Fellowship (1958-59)

Citation for distinguished service in the field of music, Yale School of Music (1968)

Merit Award, Government of Alberta (1970)

Creative and Performance Award, City of Edmonton (1972) 
Certificate of Appreciation for significant contributions in the field of "Women in the Arts," City of Edmonton (1976)

Guest lecturer and composer at "Women in Music," School of Music, University of Oklahoma (1976)

Queen's Silver Jubilee Medal for long and distinguished service in the field of music (1978)

Lifetime Academic Member of the Accademia Tiberina of Rome, Italy (1979) Award for Outstanding Success in Concert Music, Performing Rights Organization of Canada Ltd. (1981)

Award of Merit, McGill University Alma Mater Fund (1982)

Special Award for outstanding contribution to cultural life of Alberta,

Celebration of Women in the Arts (May 1983)

Order of Canada (December 1983)

"Composer of the Year," The Canadian Music Council (March 1984)

Award for "Women in the Arts," YMCA (May 1985)

Fellowship of the Royal Canadian College of Organists, Honoris Causa,

National Convention of the Canadian College of Organists (July 1985)

Ornamental park named in her honor, Edmonton, Alberta

"The Violet Archer Music Festival" (18-20 October 1985)

Inducted into the Cultural Hall of Fame, Edmonton (March 1987)

Sir Frederick Haultain Prize, Government of Alberta (1 June 1987)

The Canadian Music Centre, Prairie Region Library in Calgary became the

Violet Archer Library (13 November 1987)

Life Achievement Award, Province of Alberta and Canadian Broadcasting Corporation (18 September 1990)

Award of Merit, McGill University Alma Mater Fund (25 September 1991)

Great Canadian Award, Edmonton (22 June 1992)

Violet Archer Fellowship, University of Alberta (9 October 1992)

Medal and Citation commemorating the 125th Anniversary of Confederation 1967-1992, Governor General of Canada

The Twentieth-Century Award for Achievement by the International Biographical Centre, Cambridge, England

International Woman of the Year, 1992-93, International Biographical Centre of Cambridge, England (9 July 1993)

Most Admired Woman of the Decade, American Biographical Institute (23 July 1993)

Women's Inner Circle of Achievement, American Biographical Institute (5 August 1993)

Woman of the Year, American Biographical Institute (1993)

Fellowship of the International Biographical Association of Cambridge, England (April 1994)

International Order of Merit, International Biographical Centre, Cambridge, England (1994)

Who's Who at the Summit, American Biographical Institute (1994)

Gold Record of Achievement, American Biographical Institute (1994) 